\title{
BÓCZ ENDRE
}

\section{Az úgynevezett „romagyilkosságok” ügyéről}

Amikor 2008 júniusában a sajtó hírül adta, hogy másodikára virradóan, az éjfél utáni percekben puskával belőttek a debreceni menekültszállás épületébe, valószínüleg senki nem gondolta, hogy ez nem is a kezdete egy olyan eseménysorozatnak, amely azután több évig foglalkoztatja majd a hatóságokat, meg a magyar, sőt a nemzetközi közvéleményt.

\section{Az eseménysor és a nyomozás}

A visszhangok a szokásosnak tekinthetö törésvonalak szerint oszlottak meg: egyesek éretlen csínynek, mások a már-már aggasztó mértékü idegengyülölet újabb megnyilvánulásának tartották a történteket. Csak mellékes körülményként jött szóba, hogy a szálláson lakó koszovói menekültek között romák is vannak, és az esemény néhány nap alatt feledésbe is merült.

Jó másfél hónappal később, július 22-re virradóra, éjfél után a Pest megyei Galgagyörkön történt egy újabb esemény, amelyet két másikkal is kapcsolatba hoztak.

A településen korábban egyes roma klánok és nem roma lakosok között súlyos, rendőri intézkedéseket kiváltó nézeteltérések voltak. E viszályba azután a vitatott létjogosultságú Magyar Gárda is beleavatkozott, és ezért a helység neve annak idején sokat szerepelt a sajtóban. Most ismeretlenek három, romák által lakott épületre több lövést adtak le részben golyós, részben sörétes puskából. Az érintett roma családoknak a korábbi eseményekben nem volt ismert szerepük ugyan, de az érdekeltségük kizárt sem volt, az elözmények tükrében pedig az is felvetődött, hogy pusztán csoport-hovatartozásuk okán kerültek ők - illetve a házaik - a célpontba.

Közel három héttel később, az augusztus 8-ra virradó éjszaka 1.10-kor a Szabolcs-Szatmár-Bereg megyei Piricsén gyújtópalackokkal - közismert néven Molotov-koktéllal - támadtak két romák által lakott házra, majd sörétes puskából lövöldözve elmenekültek.

Ezek az események egymástól távoli településeken, három különböző rendőri nyomozó hatóság illetékességi területén történtek, és többféle indo- 
kot is lehetett feltételezni. Igaz, a romák elleni rasszista gyülölet is számításba jött, de távolról sem volt domináns. Ezen az sem változtatott, hogy nagyjából egy hónap múlva, szeptember 5-én 0.10-kor a Hajdú-Bihar megyei Nyíradony-Tamásipuszta, Jázmin utca 2. számú épület szobaablakát áttörve golyós puskából kilőtt két lövedék csapódott be a lakóhelyiségbe. Ez a támadás nem váltott ki különösebb sajtóvisszhangot, bár erősítette azt a feltételezést, hogy kifejezetten romák ellen folyik támadássorozat. A három héttel később, 2008. szeptember 29-én, a Heves megyei Tarnabodon történtek azonban ezt megint kétségessé tették, mert itt - a korábbiakhoz hasonló módon - gyújtópalackokkal, továbbá golyós és sörétes puskákból szinte kizárólag ablakokra leadott 29 lövéssel éjjel 1 és 1.30 között támadtak meg öt épületet, de ezek egyikében sem laktak romák.

E támadások ekkor már állandó témái voltak a sajtónak. Többen felfigyeltek az egyes események hasonló vonásaira: a támadások mindig éjjel, éjfél körül indultak, és a célpontjuk rendszerint a település szélén lévő épület volt, eszköze pedig házilag barkácsolt gyújtópalack, továbbá lőfegyver: golyós és sörétes puska. Ez arra mutatott, hogy a támadók legalább ketten vannak, s ezt támogatta két olyan vallomás is, amelyben a tanú két támadóról számolt be. Kézenfekvő volt az a feltételezés, hogy a támadók mindenütt ugyanazok lehetnek. Szembeszökő, hogy a gyújtópalackok többsége csődöt mondott; mindössze Tarnabodon keletkezett két kisebb lakástűz, amelyeket a tüzoltóság közremüködése nélkül maguk a lakók eloltottak. Az ablakokra leadott lövések folytán a lakótérbe behatoló lövedékek (sörétrajok) sérülést eddig senkinek nem okoztak, bár szinte minden esetben tartózkodtak ott emberek.

2008. november 2-án éjfél körül a Borsod-Abaúj-Zemplén megyei Nagycsécs községben gyújtópalackot dobtak a Dózsa György út 7. és 8. számú házakba, majd sörétes puskából lövéseket adtak le az ablakokra. A 7. számú házban nem keletkezett tüz, a 8. számú azonban kiégett, s lakói közül Nagy Tiborné és Nagy József a sörétes puskából leadott lövések folytán szinte azonnal meghalt. A haláleset új dimenziót adott a támadásoknak.

2008. december 15-én 17 óra körül a Borsod-Abaúj-Zemplén megyei Alsózsolcán, a Dankó Pista utca 20. számú ház udvarán tűzifával foglalatoskodó Rontó Krisztián a Sajó túlpartjáról - nyilvánvalóan célzottan - kilőtt puskagolyótól életveszélyes sérülést szenvedett. Ez már világos nappal történt, és félreérthetetlenül gyilkos szándékról árulkodott.

2009. február 23-án 0.15 és 0.30 között a Pest megyei Tatárszentgyörgyön a padlástérbe, valamint a bejárati ajtó üvegét betörve a lakásba dobott gyújtópalackkal felgyújtották Csorba Róbert Fenyves sor 3. szám alatti házát, és 
a ház előtt, a bejárati ajtó közvetlen közelében, lesből, sörétes puskából leadott lövésekkel halálra sebezték a gyermekeit mentő Csorba Róbertet és ötéves kisfiát. Kislánya, a hatéves Csorba Bianka ugyanezektől a lövésektől súlyosan, bár nem életveszélyesen megsebesült.

A következö büntett 2009. április 22-én, 22 óra után néhány perccel történt. A Szabolcs-Szatmár-Bereg megyei Tiszalökön, a Nefelejcs utca 27. számú ház udvarán szíven lötték a munkába induló Kóka Jenöt, aki azonnal meghalt.

2009. augusztus 3-ra virradóra, éjfél körül, a Szabolcs-Szatmár-Bereg megyei Kislétán, a Bocskai utca 7. számú házban rátörték az ajtót az alvó özvegy Balogh Máriára és a kiskorú Pótor Tímeára, és sörétes puskák közvetlen közelről leadott lövéseivel az elöbbinek azonnali halálához vezető, az utóbbinak életveszélyes sérüléseket okoztak.

A halálos következménnyel járó nagycsécsi támadás után nyilvánvalóvá vált, hogy a támadássorozat nem valamilyen meghatározott sajátos, egyedi ok alapján kiválasztott személyek, hanem - egyéb személyes tulajdonságaira tekintet nélkül - a roma népességhez tartozók közül véletlenszerüen kiválasztott áldozatok ellen irányul.

Az eddig a különböző megyék rendőr-főkapitányságain folyó nyomozásokat a Nemzeti Nyomozó Iroda vette át, az ügyeket egyesítették, és az Országos Rendőr-főkkapitányság Bűnügyi Szakértői és Kutatóintézetében a kilőtt töltényhüvelyeken lelt fegyvermüködési nyomok alapján a fegyverszakértő megállapította, hogy az ismeretlen tettesek azonos fegyvereket használtak Galgagyörkön, Piricsén, Tarnabodon és Nagycsécsen. ${ }^{1}$ A büncselekményeknél használt fegyverek eredetét azonban homály fedte.

A Nemzeti Nyomozó Iroda 2009. augusztus 21 -én azonosította az elkövetőket, és a rendőrség elfogta, örizetbe vette, a bíróság pedig előzetes letartóztatásba helyezte öket. Az aprólékos, széles körü, alapos és hosszas nyomozás keretében tisztázódott, hogy a lefoglalt számos fegyver közül melyiket melyik gyanúsított használta, melyikből hol milyen lőszert és milyen célpont ellen lőttek ki. Az azonban csak 2010 januárjában derült ki, hogy a Debrecenben lefoglalt fegyvereket a Jász-Nagykun-Szolnok megyei Besenyszögön, 2008. március 7-re virradó éjjel 0.15 és 0.35 között négy ismeretlen álarcos Gazdag Csaba hivatásos vadász Nefelejcs utca 5. szám alatti lakásáról fegyverrel vagy fegyverutánzattal való fenyegetés útján rabolta el. ${ }^{2}$

1 A Budapest Környéki Törvényszék 8 B. 101/2010/1010. számú ítélete. I. kötet, 294. o.

2 Uo. 131. o. 
2009. augusztus 26-án Kiss István részletes beismerő vallomást tett arról, hogy gyermekkorától milyen sérelmek érték őt romák részéről, s hogy ezek miatt ellenszenvet táplált velük szemben, amely végül a szkinhedekhez vezette, később pedig a Véres kard nevü szélsőséges csoport tagja lett. A 2006 őszén Olaszliszkán történt lincselés, majd a galgagyörki viszály híreinek hatására kialakult az a meggyőződése - s ebben mind a bátyja, Kiss Árpád, mind két másik társa, Pető Zsolt, és a csoportjukhoz később csatlakozó Csontos István is osztozik -, hogy az igazságszolgáltatás mindezt nem kezeli megfelelően. Ezért határozták el eredetileg hárman, hogy megrendszabályozzák a romákat. Nem megölni akarták őket - hangsúlyozta Kiss István -, hanem csak félelmet akartak kelteni bennük; olyan félelmet, ,hogy megtudják: milyen az, ha az ember fél egy másik néptöl", és ezt úgy akarták elérni, hogy löfegyvereket szereznek, és megfélemlítésül rálőnek a romák házaira. ${ }^{3}$

A nyomozás idején Kiss Árpád és Kiss István elismerte részvételét a galgagyörki, piricsei és tarnabodi lövöldözésben, de tagadták a rablásban és az emberhalállal végződő cselekményekben való részvételüket, Pető Zsolt pedig tagadta a bünösségét, de a tényeket illetően semmiféle nyilatkozatot nem tett sem a nyomozás során, sem a tárgyaláson.

A Pest Megyei Föügyészség 2010. szeptember 10-én nyújtott be az ügyben vádiratot a - még Pest Megyei Bíróság nevü - Budapest Környéki Törvényszékhez. ${ }^{4}$

\section{A vád}

A vád Kiss Árpád, Kiss István és Pető Zsolt ellen részben mint társtettesek, részben mint bünsegédek, Csontos István ellen pedig mint bünsegéd ellen ,, 1 rendbeli, a Btk. 166. § (1) bekezdésébe ütközö és a (2) bekezdés a), c), f), g), és i) pontja szerint minösülö, elöre kitervelten, aljas indokból, több emberen, részben sok ember életét veszélyeztetve, részben tizennegyedik életévét be nem töltött személy ellen elkövetett emberölés büntette" volt, továbbá a Kiss testvérek és Pető Zsolt ellen társtettesi minőségben egyrendbeli, fegyveresen és csoportosan elkövetett rablás, és egyrendbeli löfegyverrel és löszerrel való visszaélés büntette. Kiss Árpád ellen ezen felül egyrendbeli, a Btk. 171. $\S$ (1) bekezdésébe ütközö, de a (3) bekezdés I. fordulata szerint minősülö foglalkozás körében elkövetett veszélyeztetés büntette miatt is vádat emeltek.

3 Uo. 145 . o

4 NF. 5431/2008/174-I. 
A 85 oldalas vádirat 10. oldalán, a vádlottak személyiségének jellemzése után az olvasható, hogy „,2007. év végén 2008. év elején nézeteik hangoztatásán, közös megvitatásán túllépve I. $r$. Kiss Árpád, II. $r$. Kiss István és III. $r$. Petö Zsolt arra az elhatározásra jutottak, hogy miután a törvény és az igazságszolgáltatás nem látja el megfelelöen a feladatát a romákkal kapcsolatosan, saját kezükbe veszik a rendcsinálást oly módon, hogy fegyveres támadást hajtanak végre roma nemzetiségü személyek lakta házak ellen. Kezdeti elgondolásuk szerint a tervbe vett cselekményük a félelem felkeltését célozta a roma emberek körében." E megállapodás végrehajtása volt a vád tárgyává tett büncselekmény-sorozat. ${ }^{5}$

A vádhatóság a II. vádpont kivételével valamennyi olyan cselekmény mögött, amelynek keretében a vádlottak lakóhelyiségek ablakaira adtak le lövéseket, emberölési szándékot vélelmezett. Amikor viszont Kiss Árpád golyós puskából rálőtt a debreceni menekültszállás folyosójának kivilágított ablakára, abban a tudatban, hogy az épületben emberek tartózkodnak, a vád szerint az ott lakók életét, testi épségét szándékosan veszélyeztette ugyan, de a halálos végkimenetelnek - ellentétben a jóval kisebb alapterületü lakószobákkal - olyan elhanyagolható volt a valószínúsége, hogy ezzel nem is kellett reálisan számolnia. ${ }^{6}$

Azt, hogy gyújtópalackok használatával több helyen tüzeket - és ezek révén tetemes anyagi károkat - okoztak, a vádhatóság figyelmen kívül hagyta, mert sehol nem fenyegetett a tüz tovább terjedése, s így nem keletkezett közveszély; a tủz által okozott rongálás nem volt vád tárgya.

\footnotetext{
5 Az ügyben alkalmazott 1978. évi IV. törvény 137. § 7. pontja szerint: „,bünszövetség akkor létesül, ha két vagy több személy büncselekményeket szervezetten követ el, vagy ebben megállapodik, és legalább egy büncselekményt elkövetnek, de nem jön létre bünszervezet” - vagyis (ugyanezen paragrafus 8. pontja szerint): „, három vagy több személyböl álló, hosszabb idöre szervezett, összehangoltan müködö csoport, amelynek célja ötévi vagy ezt meghaladó szabadságvesztéssel büntetendö szándékos büncselekmények elkövetése”. A vádbeszédben indokolja az ügyész azt a (vádemelésnél követett) álláspontot is, hogy miért nem szerepel a vádban a bünszervezeti elkövetés, de ez arra nem magyarázat, hogy miért nem minősítették a rablást a 321. § (3) bekezdés c) pontjának I. fordulata szerint is. Lásd Vádbeszéd. Kézirat, 103. o.

6 A megállapított tények szerint Kiss Árpád a lövés leadásakor a célba vett ablakon át nem látott be az épületbe, és nem tudta, hogy Hasani Kenedi éppen nyitotta a 214. számú szoba ajtaját azzal a szándékkal, hogy kimenjen a folyosóra. Az az ítéleti ténymegállapításból (A Budapest Környéki Törvényszék 8 B. 101/2010/1010. számú ítélete. I. kötet 39. o.) nem derül ki, merre nyílt az ajtó, tény viszont, hogy a lövedék a kb. negyvenfoknyira nyitott ajtó lapját a padlószinttől 105,5 cm magasságban fúrta át, és tovább repült, tehát átszelte a légteret az ajtónyílás vetületében, vagyis másodpercek töredékén múlt, hogy Hasan Kenedi - testmagasságától függően - nem szenvedett esetleg halálos (feltehetően mellkasi) sérülést, ami e szerint a Btk. 171. § (1) bekezdésébe ütköző, és a (2) bekezdés b) pontja szerint minősülő foglalkozás körében elkövetett halált okozó veszélyeztetésnek - és nem emberölésnek - minősülne.
} 


\section{A bírósági eljárás és az ítéletek}

E vád elbírálása érdekében folytatta tehát a hosszú, fordulatokban is bővelkedő tárgyalást a Budapest Környéki Törvényszék, amely rendkívül széles körủ és részletekbe menő bizonyítás nyomán aprólékos, és a Budapesti Ítélootábla szerint is megalapozott, gondosan megindokolt tényállást állapított meg. Ez a tényállás most már, a Be. 388. § értelmében - emberi számítás szerint lényegesen aligha változik, tehát irányadónak tekinthető.

A két év és öt hónap alatt 186 folytatólagos tárgyalási napot felölelő tárgyalás után, 2013. augusztus 6-án kihirdetett ítéletben a törvényszék kimondta, hogy a vádlottak bünszervezetet hoztak létre. A besenyszögi rablást, mivel az egyik elrabolt puska Gazdag Csabáné tulajdona volt, kétrendbelinek minősítette, a lőfegyverrel és lőszerrel való visszaéléssel alaki bünhalmazatban haditechnikai termékkel való visszaélés miatt is megállapította a bünösséget, Kiss Árpádnak a debreceni menekültszálláshoz kapcsolódó cselekményét is emberölési kísérletnek, és az emberölési cselekményeket különös kegyetlenséggel elkövetettnek is minősítette. Mellőzte viszont a Btk. 166. § (2) bekezdés g) pontjának - ,sok ember életét veszélyeztető módon”- alkalmazását.

A Budapesti Ítélőtábla már másodfokon is döntött az ügyben. Az emberölési cselekményeket részben védekezésre képtelen állapotban lévő személy sérelmére elkövetettnek is minősítette, a haditechnikai termékkel való visszaélés halmazati megállapítását pedig mellőzte, és kimondta, hogy a besenyszögi rablásban érintett vádlottak Gazdag Csabáné, kiskorú Gazdag Diána és kiskorú Gazdag Renáta személyi szabadságának megsértésében is bünösök azért, mert a távozáskor őket is megkötözték.

\section{Szokatlan jogi megoldások}

Mint látható, a hatalmas tömegü bizonyítási anyagot feldolgozó elsőfokú ítélet a másodfokú bíróság előtt jól „,vizsgázott,” csak jelentéktelennek tekinthető változtatásokat vezetett rajta át az ítélőtábla. A laikus közvélemény - ha a médiát a tükrének tekintjük - a jelek szerint ugyancsak elégedett. ${ }^{7}$ A következő fejtegetésekre engem sem az indít, hogy érdemleges kifogásom lenne az ügy végkimenetelét illetően, hanem az, hogy - mint egykori hivatását szere-

7 Kivéve, persze, azokat, akik a jogrendszerrel elégedetlenek a halálbüntetés hiánya miatt. 
tő nyugdíjasnak - többirányú ,,jogesztétikai " hiányérzetem van az óta, hogy alkalmam nyílt a vádiratot elolvasni.

1) A , több emberen elkövetett emberölés” büntette ${ }^{8}$ úgynevezett „,̈sszefoglalt büncselekmény" (delictum compositum), amely akkor válik befejezetté, ha mindazok - de legalább két ember - megszüntek élni, akiket az elkövető meg akart ölni. Fogalmi képtelenség e büncselekmény valóságos homogén anyagi bünhalmazata, és ezért szükségtelen az „egyrendbeli” kitétel alkalmazása. Másrészt: amíg akár csak egy is él a sértettek közül, a jogászi szabatosság megköveteli annak megemlítését, hogy a büntett „,részben kisérlet”. Ez apróság, ám egy ilyen széles - azt sem túlzás mondani: nemzetközi - érdeklődést kiváltó bünügyben, amelynek iratai kétségtelenül hosszú ideig kutathatók lesznek a levéltárban, úgy gondolom, ilyesmire is érdemes lett volna ügyelni.

A kasszációs fellebbezési rendszer bevezetése nyomán praktikus okokból teret hódított az a gondolat, hogy a szándékosság, gondatlanság, célzat stb. tényekből adódik ugyan, de a felülbírálás szempontjából „,tényekböl levont jogi következtetés", és a fellebbezési eljárásban ${ }^{9}$ nem tény-, hanem jogkérdésként kezelendő. Így fokozatosan háttérbe szorult az a követelmény, hogy a szándékosságot, célzatot stb. megalapozó tényeknek szerepelniük kell a vádban. ${ }^{10}$

Újabban azonban hangsúlyozottan jelentkezik ez az igény a vádhoz kötöttség lobogója alatt. ${ }^{11}$

Ebből a szempontból különösen érdekes a II. vádpont.

A vád tárgya az a tény, hogy Kiss Árpád 2008. június 2-án 0.05-kor kb. 260 m távolságról mintegy $30 \mathrm{mp}$ időközzel két lövést adott le a debreceni menekültszállás épületének északkeleti homlokzatán lévő kivilágított folyosóablakra, holott tudta, hogy az épületben emberek laknak, akik a folyosón járkálhatnak, tehát a lövedék eltalálhat valakit és így sérülést, vagy akár halált is okozhat. A vádlott volt katona, tudta, hogy a fegyverkezelési szabályok szerint békeidőben általában tilos olyan irányba lőni, amelyben a lövedék röppályáját nem látja be, és különösen, ahol emberek mozoghatnak. E foglalkozási szabálynak minősülő tilalmat tehát szándékosan szegte meg.

8 1978. évi V. törvény (Btk.) 166. $§$ (1) bekezdésébe ütköző és a (2) bekezdés f) pont.

9 De csak ott! Anyagi büntetőjogi - azaz bűncselekménytani - szemszögből tehát nem!

10 Amikor 1961-ben ügyészségi fogalmazó lettem, instruktoraim kifejezetten feleslegesnek és kerülendőnek mondtak minden ilyen vádirati szöveget. 1978 után, föügyészhelyettesként viszont megköveteltem a kiadmányozási körömbe tartozó vádiratokban a szándékosság vagy gondatlanság megfelelő alakzatára vonatkozó szövegszerü tényállítást.

11 Lásd Elek Balázs: A ,tudati tények” a büntetőítéletben. Magyar Jog, 2014/1., 24. o. 
A lövés így önmagában veszélyt jelentett, de ez a veszély nem volt közvet$l e^{12}$, mert nincsen olyan adat, amely arra mutatna, hogy a löirányban tényleges mozgás lett volna e késői órában. A vádlott által kilőtt második lövedék viszont átszelte a légteret az ajtónyílás vetületében, vagyis másodpercek töredékén múlt, hogy Hasan Kenedi - aki az első lövés zaja által keltett kíváncsiság hatására kilépőfélben volt a folyosóra - nem szenvedett esetleg halálos (feltehetően mellkasi) sérülést. Ez már közvetlen veszély volt, ám annak kialakulásában lényeges Hasan Kenedi mozgása, amelyről mint tényről a vádlottnak a lövés pillanatában nem volt tudomása, noha a töle elvárható körültekintés esetén hasonlóra számíthatott volna. Itt tehát szerepet kap(hatott volna) a Btk. 27. § (1) és (3) bekezdése: a veszély közvetlenségére a szándékosság nem terjedt ki.

2) Arra nem volt nehéz rájönni, hogy a III-XI. vádpontban leírt cselekményeket a vádhatóság kivétel nélkül több emberen elkövetett emberölésként kezeli - függetlenül attól, hogy történt-e haláleset, vagy sem -, és a törvényi egység keretében rója fel. A tényleíró részekben - a gyakorlatnak megfelelően - a „tudati tények”-ről nem esik szó. Kiss István és Pető Zsolt mindig tagadta, hogy Galgagyörkön, Piricsén, Tarnabodon ölni szándékoztak volna; a vaktában való, összevissza lövöldözéssel, gyújtópalackokkal csak félelmet akartak kelteni. Állították, hogy személy szerint senkit nem vettek célba. Kiss István mindig hangoztatta azt is, hogy Piricsén lőtt ugyan annak az ajtónak az irányába, amelyen Gyetyinás Magdolna kijönni készült, de nem örá célzott, és lábmagasságba irányozta a csőtorkolatot.

Az ügyész a vádbeszédben azzal érvelt, hogy mind a golyós puska lövedéke, mind a sörét okozhatott volna halált, s hogy ez nem következett be, az nem a vádlottakon múlott; a vádlottak nem látták, hogy a lakók ténylegesen hol tartózkodnak a sötét helyiségekben. „Nem akarták ugyan megölni a sértetteket, ám nem törödtek azzal, hogy a lövések következtében a bent lakók közül valaki esetleg az életét veszti. Mivel kizárólag az lebegett a szemük elött, hogy a megtorló akcióval félelmet váltsanak ki a roma lakosság körében, közömbösek voltak a halálos eredmény bekövetkezését illetöen" mondta, hozzátéve, hogy ezek a cselekmények emberölés úgynevezett „teljes”, „befejezett kísérletei”, az emberölési szándékot tükrözi az is, hogy ismételten is löttek egy-egy helyre, és nagyszámú lövést adtak le. Tarnabodon összevissza, ,vakon” lövöldöztek a házakba, illetve az utca vo-

12 Vö. Kereszty Béla - Maráz Vilmosné - Nagy Ferenc - Vida Mihály: A magyar büntetőjog Különös Része. Egyetemi tankönyv. Második, átdolgozott kiadás. Korona Kiadó, Budapest, 2005, 124. o. 
nalában, nem törődtek azzal, hogy a házakban, vagy a házak előtt tartózkodó személyek életüket vesztik.

A törvényszék még ennél is szigorúbb álláspontra helyezkedett, és még a II. vádpontban leírt cselekményt is emberölésnek minősítette.

Érvelésében hivatkozott a Legfelsőbb Bíróság 15. számú irányelvének arra a tantételére, hogy a löfegyver használata általában emberölési szándékra enged következtetni, továbbá hogy e mellett vizsgálni kell az elkövető személyiségét és motívumait. Utalt arra, hogy a vádlottak kifejezetten azért szereztek löfegyvereket, hogy azokkal romák elleni büncselekményeket kövessenek el, s így félelmet keltsenek mind a sértettekben, mind általában a roma népességben. További érv, hogy Kiss Árpád a vád tárgyául szolgáló esetben olyan ablakra célzott, amely mögött reálisan számolnia kellett azzal, hogy bármikor megjelenhetnek emberek, és azt is tudta, hogy fegyvere ,„nem konkrétan emberre leadott lövés esetén is okozhat halált. [...] Az eredmény elmaradását a véletlenre bizni nem egyéb, mint az eredmény bekövetkezésébe való belenyugvás" - ami ebben az esetben azonos az emberölésre irányuló eshetőleges szándékkal. ${ }^{13}$

3) Annak sem az ügyész, sem a törvényszék nem tulajdonított jelentőséget, hogy Kiss István Piricsén lefelé irányozta a csőtorkolatot. ${ }^{14}$

Tény viszont, hogy Galgagyörkön három, Nyíradony-Tamásipusztán egy, Tarnabodon öt ház ablakán löttek be, 41 lövés irányult a házakra, főként az ablakokra, illetve az ablakokon át a lakóhelyiségekre, és ezekből egyetlen személysérülés sem keletkezett. ${ }^{15}$ Ebben valószínüleg nem csekély szerepe van annak, hogy a cselekményeket éjfél körül követték el, a házbeliek már aludtak. A sötét ablakok mögötti lakóhelyiségek bútorzatának elrendezéséről - például a fekhelyek hollétéről - a vádlottaknak fogalmuk sem volt. A bent lévők többnyire az ablakpárkány síkjánál alacsonyabban lévő fekhelyen aludtak, a lakótérbe bejutó lövedékek röppályája általában az alvók testénél magasabban szelte át a lakóhelyiséget, és a fekhelyek maguk is nem egyszer a fal holtterében álltak. Az is előfordult, hogy a lakók nem is voltak a megtámadott helyiségben.

Aki egy lakóhelyiség ablakára abban a tudatban ad le tüzfegyverből célzott lövést, hogy a célba vett ablak mögött emberek vannak, annak óhatatlanul tudnia kell - mert ez közismeret -, hogy a lövedék az útjába kerülö objektumot (legyen az akár tárgy, akár élőlény) károsítja. Nyilvánvaló tehát, hogy az ablakon áthatoló lövéssel meg lehet valakit sebesíteni, vagy akár

13 A Budapest Környéki Törvényszék 8 B. 101/2010/1010. számú ítélete. II. kötet, 853. o. 14 Vádbeszéd. Kézirat. 95-96. o. 
ölni is. Ennek fizikai előfeltétele az, hogy a lövés embert találjon el, és fiziológiai előfeltétele, hogy olyan sérülést okozzon, amely halálos lehet.

A gurulat, vagy - sörét esetén - a normál szóródás ${ }^{16} e ́ s$ a gurulat lehetöségét, és azt is figyelembe véve, hogy a gurulatot esetleg okozó berendezési tárgyak elhelyezkedése az adott lakóhelyiségben ismeretlen, a lövedékek röppályája kiszámíthatatlan. Minden ilyen lövésnek közvetlen és közismeretként elöre látható következménye az, hogy kiszámíthatatlan röppályán mozgó lövedéket repít a hatókörét alkotó térben (a lakóhelyiségben) tartózkodó emberek közé, kitéve így őket annak, hogy közülük egyet vagy többet eltalál, és (akár halálos) sérülést okoz. Ezek az ismeretek - amelyek a testi épség veszélyeztetésétől az élet kioltásáig minden lehetséges következményt átfognak - alkotják a lövést vezérlő pszichikai viszony intellektuális tartalmát. Ez a viszony büntetőjogi értelemben: az élet és testi épség veszélyeztetésére irányuló szándékosság. A helyiségben tartózkodó személyek tényleges elhelyezkedésének ismerete híján az, aki a lövést leadni szándékozik, nem tudhatja, hogy a lövedék a fegyvercsö térbeli helyzete által meghatározott aktuális lőirány folytán hová csapódik majd be, hogyan változtat esetleg röppályát, és kinek milyen sérülést okoz, ezért a lövést vezérlő szándékosságba - a Btk. 27. § (1) bekezdése értelmében - az esetleg okozott emberhalál sem egyenesen, sem eshetőlegesen nem számítható be.

4) Talányos elgondolást tükröz a törvényszék ítéletében olvasható ama mondat, hogy ,.... a több emberen elkövetett emberölés büncselekményét a jogalkotó súlyosabban rendeli büntetni és lényegében törvényi egységet hoz létre az által, hogy függetlenül az egymástól elkülönülő időpontokban elkövetett ölési cselekményektől, azok egy rendbeli cselekményként ítélendők meg"'17.

Mint ismeretes, a büntetőjog tudományában „összefoglalt bűncselekmény”nek az olyan büncselekményeket nevezik, amelyeknek törvényi tényállása több, külön-külön önmagában is büncselekménynek minősülő cselek-

\footnotetext{
15 Csak Gyetyinás Magdolna szenvedett - Kiss Istvánnak a fegyverszakértői vélemény szerint „derék-” (azaz kb. $120 \mathrm{~cm}$ ) magasságból adott lövésétől a bal combján és lábán térd alatt, meg a bal könyökén sörétszemek által okozott és összességében nyolc napon belül gyógyuló sérüléseket. A sörétraj a ház utca felől nézve jobb oldali falán hagyott a talajszinttől mért 50-130 közötti magasságban - tehát a csőtorkolatnál alacsonyabban - hosszú becsapódási nyomot - lásd a Budapest Környéki Törvényszék 8 B. 101/2010/1010. számú ítélete. II. kötet, 568. o.

16 A sörétrajt alkotó sörétszemek - miután elhagyták a csőtorkolatot és kiszabadultak a lehulló sörétkosárból, divergáló röppályát követnek, és egyre nagyobb területet fednek le.

17 A Budapest Környéki Törvényszék 8 B. 101/2010/1010. számú ítélete. II. kötet 850. o. (kiemelés tölem - B. E.)
} 
ményt ${ }^{18}$ egyesít egyetlen büncselekménnyé. A több emberen elkövetett emberölés büntettének e minősített esetét mint összefoglalt büncselekményt legalább két olyan cselekmény létesíti, amelyek mindegyike megfelel az emberölés alapesetét megfogalmazó Btk. 166. § (1) bekezdés követelményeinek. Az összefoglalás folytán ezek egyetlen büncselekménnyé válnak, vagyis nem alkotnak valóságos anyagi bünhalmazatot. Az egyes cselekmények azonban nem olvadnak össze, tehát nem válnak egyetlen cselekménynyé; a „cselekmény” tények foglalata, így ez lehetetlen is lenne. Megőrzik azokat a jellegzetességeiket is, amelyek például a törvény szerint súlyosabban minősítő körülmények, s ezeket meg kell állapítania az ítélőbíróságnak is.$^{19}$ Lehetséges, persze, hogy csak a szóhasználat pongyola az ítéletben, de az indokolásban később olvasható fejtegetések - például hogy a törvényi egység folytán ,, a cselekmény minösitö körülményeit, amennyiben az nem egy objektív körülménytöl függ, nem lehet az egyes elkövetési helyszínekre külön-külön szétbontani " ${ }^{20}$ - inkább arra mutatnak, hogy a törvényszék nem igazodott az egyetemi tananyagban szereplö büncselekménytani felfogáshoz, hanem valamilyen sajátos gondolatrendszert követett.

5) Ezt erősíti az a gondolatmenet is, amelyet a „különös kegyetlenség”-gel mint súlyosabban minősítő körülménnyel kapcsolatban fejtett ki. ${ }^{21}$

Helyesen elemzi ugyan a tüzhalálra vonatkozó ismereteket, de nem tulajdonít annak jelentőséget, hogy mindez arra az esetre vonatkozik, ha a jelzett kínokat a halál beállta előtt kell - az elkövető szándéka szerint - az áldozatnak elszenvednie. Erre azonban a jelen ügyben nincsen egyetlen ténymegállapítás sem. Az agyonlőtt áldozatok mindegyike - a megállapított tények szerint - a halálos lövések következtében perceken belül, többnyire szinte azonnal elhunyt. Arra utaló adat sincsen, hogy valakit ténylegesen tűzhalál fenyegetett volna, mert nem menekülhetett volna az égő épületből,

\footnotetext{
18 Vagyis büncselekmények egyébként valóságos anyagi halmazatát.

19 Az összefoglalt büncselekmény szabatos megnevezése „több emberen elkövetett emberölés büntette”. Ha más, súlyosabban minősítő körülményeket is megállapít a bíróság, akkor azokat, amelyek valamennyi részcselekményre vonatkoznak, az idézett megnevezésben az „emberen” és az „elkövetett” szavak között (például „több emberen, előre kitervelten...”), azokat pedig, amelyek csak egyes részcselekményekre érvényesek, ez után (például „,részben különös kegyetlenséggel, részben aljas célból”, stb.) kell felsorolni. Természetesen meg kell jelölni a megfelelő részcselekményeket. Vö. Kereszty Béla - Maráz Vilmosné - Nagy Ferenc - Vida Mihály: i. m. 91. o. Ha nem valamennyi passzív alany hal meg, tehát a büncselekmény részben kísérleti stádiumban marad, a megnevezésben ezt is érzékeltetni kell.

20 A Budapest Környéki Törvényszék 8 B. 101/2010/1010. számú ítélete. II. kötet, 854. o. és visszautal erre a különös kegyetlenséggel összefüggésben erre a 858. oldalon is.

21 A Budapest Környéki Törvényszék 8 B. 101/2010/1010. számú ítélete. II. kötet, 857. és köv. o.
} 
sőt Nagycsécsen a szellemi állapota miatt menekülésre képtelen Nagy Máriát is akadálytalanul kimentették, mielőtt égési sérülést szenvedett volna. Tatárszentgyörgyön sem azért okozták a tüzet, hogy a lakók tủzhalált szenvedjenek, hanem azért, hogy a tüz elöl menekülő személyeket lövéssel öljék meg. A , különös kegyetlenség” mint súlyosabban minősítő körülmény alkalmazhatósága tehát több mint vitatható.

\section{A terrorcselekményről}

A közvádlói hatóság a cselekmények szervezettségének nem tulajdonított jogi minősítésben érzékeltethető jelentőséget.

A törvényszék az ítélet indokolásának elején részletes tényállást állapított meg arról, hogy a vádlottak bủnszervezetet alkottak. E szerint: Tapasztalva, hogy Kiss Istvánt szélsőséges gondolkodása szélsőséges szervezetek uszályába sodorta, őt Kiss Árpád ki akarta ebből vonni. Ezért közös nevezőként használta a cigányellenességet, és vele meg Pető Zsolttal egyetértésre jutott abban, hogy a romák által elkövetett bủncselekmények sajátos kriminológiai kategóriát alkotnak (az úgynevezett „cigánybünözés”-t), amely etnikai alapú orvoslást igényelne, s ebben - mármint a , cigányok megrendszabályozásában” - nekik ,aktívan” kellene részt venniük. Így körvonalazódott az az elgondolás, hogy lőfegyvereket szereznek, s azokkal romák által lakott településrészeket támadnak meg. ${ }^{22} \mathrm{Az}$ elgondolást tervvé formálták, ennek jegyében és végrehajtásaként rabolták el Gazdag Csaba puskáit, majd követték el a vád tárgyává tett büncselekményeiket, amelyek célja az volt, hogy megfélemlítsék közvetlenül a megtámadottakat, és mindazokat a romákat is, akik a támadásokról értesülnek. Együttmüködési rendszerüket bünszervezetnek minősítette.

A vádlottak tervében szerepelt a lőfegyver jogellenes megszerzése rablás útján, és támadó célú felhasználása - azaz az életnek és testi épségnek a löfegyver használatára és kezelésére vonatkozó (foglalkozási) szabályok megszegésével való szándékos veszélyeztetése, úgyszintén a gyújtópalackok alkalmazása - rongálásra, esetleg közveszélyokozásra - a romák megfélemlítése céljából. Az akkor hatályos Btk. 261. § (9) bekezdésének a) pontjában ezek mindegyike szerepel. Ha tehát , a lakosság megfélemlitése céljából” követik el, a Btk. 261. § (1)-(2) bekezdése alá vonható, vagyis terrorcselek-

22 A Budapest Környéki Törvényszék 8 B. 101/2010/1010. számú ítélete. I. kötet, 29. o. 
mény, és így a törvényszék által megállapított bünszervezet a Btk. 261. § (9) bekezdés b) pontja értelmében terrorista csoport.

Kiss István korábban idézett 2009. augusztus 26-i beismerő vallomását mind az ügyészség, mind a törvényszék hitelt érdemlőnek minősítette, ténymegállapítást alapozott rá. Ám sem a vád, sem az ítélet nem állapított meg terrorcselekményt, aminek csak az lehet a magyarázata, hogy a „,romák megfélemlítése” mint célzat tartalma, véleményük szerint nem felel meg ,a lakosság megfélemlitésé"'-nek. ${ }^{23}$

Nézetem szerint ez tévedés; az egész büncselekmény-komplexum helyes büntetőjogi minősítése: a Btk. 261. § (1) bekezdés b) pontjába ütköző terrorcselekménnyel elkövetett büntett, amelyet a vádlottak a bünszervezet sajátos válfajának, terrorista csoportnak a tagjaiként követtek el.

A , lakosság” egy tetszőlegesen meghatározott területet benépesítő emberek - az ott lakók - összessége. A csoportképzö ismérv, a terület, lehet akár az egész Föld, akár egy földrész, egy ország, egy település, vagy egy település körülírt része.

A területi alapon meghatározott lakosság azonban más csoportképző ismérvek segítségével további csoportokra bontható. Így beszélhetünk egy tetszőlegesen meghatározott terület férfi lakosságáról, egy-egy megye falusi vagy városi lakosságáról, magyar és nemzetiségi lakosságáról, valamely terület nyugdíjas vagy iskoláskorú lakosságáról - és ezek közül egyik szóhasználat sem kifogásolható. A főnév - és az általa jelentett fogalom - tehát rugalmas, és sokféle dimenzióban használható.

A , megfélemlités” jelentése viszonylag világos: valakiben vagy valakikben félelem keltése.

Könnyen belátható, hogy egy nagyobb terület - például egy megye vagy egy város lakossága - természetszerủen soha nem teljesen homogén, mert más csoportképző ismérvek segítségével különböző lakossági csoportokra bontható. A különféle lakossági csoportok a lakosság részei; nem különülnek el az egésztől, hanem azon belül léteznek. Az is könnyen belátható, hogy egy ország teljes lakónépességét csak rendkívüli módszerekkel lehet úgy megfélemlíteni, hogy minden egyes tagja féljen.

Hogyan értelmezhetô egy olyan félelemkeltő fenyegetés, amely egy markánsan körvonalazható szükebb lakossági csoportot vesz célba? Jól érzékelhető ez a szóban lévő eseménysorozaton.

23 A törvényszék ezt - mivel nem tért el e kérdésben a vádtól - természetesen nem magyarázta meg. 
A debreceni támadás szinte visszhang nélkül maradt - talán éppen azért is, mert a célja sem volt nyilvánvaló. Galgagyörkön kizárólag helyi roma lakosok házaira lövöldöztek. Az félreérthetetlen, hogy a támadás romák ellen irányul, de - az előzményekre tekintettel - nem volt biztos, hogy pusztán azért, mert romák; lehetett is némi alapja annak a feltételezésnek, hogy valamilyen személyükben rejlő és nem köztudomású okból voltak ők a megtámadottak. Ez még - az akkoriban sokat tárgyalt uzsoraesetekkel a háttérben Piricse után is tartható maradt, Tarnabod pedig (mivel kizárólag nem romákat érintett) még tápot is adott neki, de Nagycsécs ${ }^{24}$ után már szinte teljesen tisztázódott a kép, eltünt minden kétely.

Világossá vált - különösen a roma népesség, ,, a magyarországi roma lakosság” számára -, hogy a támadások nem személyhez kapcsolódó egyedi indokokból fakadnak, hanem a népcsoport egésze ellen irányulnak, s ezért minden olyan roma család, amelyik a támadók taktikai szempontjai szerint alkalmasnak tünő helyen lévő házban lakik, hasonló támadás potenciális célpontja.

Ebben az időben - emlékezzünk vissza - mindennap várhatónak tartották az újabb támadást. Senki nem tudta, hol és mikor csap le legközelebb az ismeretlen fegyveres csapat. Az ország egész területén fenyegetve érezték magukat a roma családok.

A már érintett megyék: Hajdú-Bihar (Debrecen), Pest (Galgagyörk), Szabolcs-Szatmár-Bereg (Piricse), Heves (Tarnabod) és Borsod-Abaúj-Zemplén (Nagycsécs) az ország területének több mint negyed részét jelentik, ${ }^{25}$ a négyhatszázezer fönyire becsült roma népesség pedig az ország teljes lakosságának mintegy négy-hat százaléka. Ebböl 245100 személy - köztük a legszegényebb, legelesettebb, és legkilátástalanabb helyzetben lévők - a felsorolt megyékben koncentrálódik.

A büncselekmények sorozatba illeszkedése ekkorra már mindenki számára nyilvánvalóvá vált, és a sorozat alakulása éppen ezért volt különösen félelmetes: Galgagyörkön és Tarnabodon talán látványosabb és zajosabb volt a támadás,

\footnotetext{
24 A Nyíradony-Tamásipusztán történt lakásba lövés esete nem keltett nagyobb visszhangot a nyilvánosságban, de természetesen azok, akik érdeklődést tanúsítottak az ügy iránt, azt is számon tartották.

25 Az ügyben érintett megyék összterülete 29427 négyzetkilométer, összlakosságuk 2836613 fö, és itt lakik az ország roma népességének közel fele, a 2003-as adatok szerint 245100 ember. Lásd Cserti Csapó, Tibor: Területi - szociológiai jellemzés a magyarországi cigány népesség körében. In: Forray R., Katalin - Beck, Zoltán (eds.): Society and Lifestyles - hungarian Roma and Gypsy communities. University of Pécs, Faculty of Humanities, Institute of Education, Department of Romology and Sociology of Education, Pécs, 2008, p. 75. ff. [Gipsy Studies 23.]
} 
több lövés esett - de itt kiégett egy ház, és ketten meghaltak. Leplezetlenné vált, hogy a támadók pusztítani és gyilkolni akarnak már, nem csak riogatni.

A Kiss testvérpár és Pető Zsolt elérte stratégiai célját: ma is köztudomású, hogy a romák országszerte rettegtek. A lakóövezeteik környékén megjelenő minden fekete autó utasaiban az ismeretlen gyilkosok felderítőit gyanították, örszolgálatokat, önvédelmi csoportokat szerveztek az eddigi támadásoktól távol eső helyeken is. Ez a légkör természetesen a valóságos élmények kissé kiszínezett változataiból és vélt összefüggésekből táplálkozó „összeesküvés-elméleteket” is szült. Ezek szájról szájra terjedtek, fokozták a feszültséget, paradox következményhez is vezettek, és - növelték a roma lakosság rettegését. ${ }^{26}$ Ezért a kérdést úgy is megfogalmazhatjuk, hogy az ország roma lakosainak összessége , lakosság”-e, és megfélemlítése a terrorcselekmény szemszögéböl kielégíti-e a minősítéshez szükséges követelményt.

Nézetem szerint igen.

A roma népesség számára - mint a kérdés egyik legelismertebb kutatója megállapítja - ,a legfontosabb megkülönböztetés maguk és a "gádzsók« (nem romák - B. E.) között húzódik”² . A területi alapon meghatározható „lakosság” egészéhez képest tehát nem tekintik magukat kívülállónak, hanem szervesen azon belül alkotnak sajátos, viszonylag markánsan körülírható, jellegzetes csoportot.

Igaz, a „bűnszervezet” támadásai (idővel jól felismerhetően) közvetlenül az érintett települések lakosságának roma csoportjai ellen irányultak, és - terveik szerint - közvetve is elsősorban az ország roma népességének a megfélemlítését szolgálták. Mégis érintették az adott település teljes lakosságát. A célpontok kiválasztásánál alapul vett konkrét ismérvek ugyanis nem voltak

\footnotetext{
26 Lásd például a tiszalöki emberöléshez kapcsolódó legendákat: a Budapest Környéki Törvényszék 8 B. 101/2010/1010. számú ítélete. II. kötet, 805. és köv. o. Az időszak légkörét jól érzékelteti Tábori Zoltán irodalmi riportgyűjteményes kötete. Tábori Zoltán: Cigány rulett. Európa Kiadó, Budapest, 2014. Paradox következmény volt, hogy azokat a romákat, akik a Magyar Gárdához tartozónak vélt és a romák lakta településrészen haladó gépkocsit feltartóztatták, majd az utasait tettlegessé fajuló vitában bántalmazták, a magyar igazságszolgáltatásban elsőként (és talán máig egyedüliként) ítélték súlyos szabadságvesztésre a Btk. azon 174/A §-a alapján, amely 1996. június 15-én lépett a Btk. nemzeti, népi, faji vagy vallási csoport tagja elleni bűncselekményt megfogalmazó 156. §-ának a helyébe. Ez a büntett a genocídiumegyezmény II. cikkelyét némiképpen átírva úgy iktatta a magyar büntetőjogba, hogy az egyezmény szerint kötelezőnél jóval szélesebb körü büntetőjogi védelmet ígért a védett csoportok tagjainak, de a romák ellen támadó szkinhedekre történő alkalmazását szorgalmazó ügyészi indítványok elől a bíróságok - élükön a Legfelsőbb Bírósággal - akár hamis érvelés árán is, de mindig kitértek, soha nem alkalmazták. Lásd erről Bócz Endre: A skinhead-ügyek és a Btk. 156. §-a. Magyar Jog, 1994/6.; Bócz Endre: A Közgazdasági Egyetemtől Tatárszentgyörgyig. Magyar Jog, 2009/11.

27 Sir Angus Fraser: A cigányok. Osiris Kiadó, Budapest, 2006, 15. o.
} 
feltétlenül megbízhatók, amire bizonyíték a tarnabodi eset: a lakóépületek külleme alapján megtámadott házakat a vádlottak romák lakhelyéül szolgáló épületeknek vélték, holott nem voltak azok. Másrészt - mint a rasszista gyülölet megnyilvánulásai, és egyben a gyülöletkeltés eszközei - alkalmasak a társadalmi feszültségek kiélezésére, a harmónia és a rend megzavarására, továbbá a társadalom különböző csoportjainak egymás ellen hangolására. ${ }^{28} \mathrm{~A}$ gyülölet effajta kifejezésének, persze, elkerülhetetlenül van egy olyan hatása is, hogy hasonló reakciót vált ki, vagyis a gyülölet viszonzására ösztönözhet. A félelem szülte roma önvédelmi csoportok híre bizonyos szorongást, sőt félelmet keltett a nem roma népesség nem egy tagjában is - bár ezzel a vádlottak aligha számoltak, s ez az ő szempontjukból nem volt kívánatos következmény. Ám - nézetem szerint - ez a célul tüzött félelemkeltésnek objektíve szükségszerü velejárója. Így szemlélve a dolgot, joggal mondható, hogy bár csak a lakosság egyik csoportjában kívántak félelmet kelteni, az erre választott módszer arra volt alkalmas, hogy a lakosság egészében félelmeket keltsen.

A közvádló a vádbeszédben magyarázatot adott arra, hogy miért nem terrorcselekmény volt a vád.

„Bár a törvény szövege látszólag megengedi a romák elleni sorozatgyilkosság terrorcselekménynek való minösitését, álláspontom szerint a terrorcselekmény speciális jogi tárgyára tekintettel a jelen eljárás tárgyát képezö büncselekményeket nem lehet terrorcselekményként minösiteni. A terrorcselekmény jogi tárgya a magyar állam és más államok, állami szervek, nemzetközi szervezetek kényszermentes cselekvöségéhez füzödö társadalmi érdek, valamint a lakosság háboritatlan életfeltételei, továbbá a személyek szabadsága és az anyagi javak sértetlenségének biztositása. A terrorcselekményt a célzata határolja el a (9) bekezdésben felsorolt büncselekményektöl.

A Btk. 261. § (1) bekezdés b) pontjában megfogalmazott célzat - ami a törvény szövege szerint a lakosság megfélemlitése - nem öncél, hanem összekapcsolódik az (1) bekezdés a) pontjában irt célzattal: az állami szerv kényszeritésével[.]" "29- mondta, de ez az érvelés nem állja meg a helyét.

A Btk. 261. (1) bekezdése szerint terrorcselekményt követ el, ,, Aki abból a célból, hogy a) állami szervet, más államot, nemzetközi szervezetet arra kényszeritsen, hogy valamit tegyen, ne tegyen vagy eltürjön, b) a lakosságot megfélemlitse, c) más állam alkotmányos, társadalmi vagy gazdasági rendjét meg-

\footnotetext{
28 Vö. az Alkotmánybíróság 30/1992. (V. 26.) AB határozatának III. pontjával, valamint a IV. pont 1. alpont első és harmadik bekezdésével. A vádlottaknak is céljuk volt a nem roma lakosság ,figyelmének felkeltése", és talán az is, hogy mintát szolgáltassanak mások számára.

29 Vádbeszéd. Kézirat, 102. o.
} 
változtassa vagy megzavarja, illetöleg nemzetközi szervezet müködését megzavarja, a (9) bekezdésben meghatározott [...] büncselekményt követ e[l]”.

A három különböző célzat tartalmát meghatározó a), b) és c) pontnak sem a szóhasználata, sem a szöveg tipográfiai elrendezése nem utal konjunktív kapcsolatra, és az egyes pontok közötti írásjelek (vesszők), amelyek helyére jól illeszkedne nyelvileg egy-egy „,vagy” kötőszó, arra mutatnak, hogy ezek egyenrangú alternatívák. ${ }^{30}$

Átnéztem néhány olyan egyetemi tankönyvet is, amely a terrorcselekménynek a vádemelés idején hatályos - és a jelenlegivel azonos - meghatározásával foglalkozik ${ }^{31}$, de csak annyiban lettem okosabb, hogy a vádbeszéd idézett gondolata ezekböl sem származhat.

E büncselekmény jogi tárgyának a tankönyvek általában a közrendet mondják, amelynek értelemszerü összetevője a magyar és más állam és szervei stb. kényszermentes cselekvése, valamint a lakosság háborítatlan élete. Arra célzás sincsen sehol, hogy a lakosság megfélemlítését mint célzatot az államzsarolási - 261. $\S(1)$ bekezdés a) pontban megfogalmazott - célzattal kontextusban kellene értelmezni. A vádbeszéd idézett részének második mondata csaknem megegyezik ugyan egy - a Pázmány Péter Katolikus Egyetemen használt tankönyv hatályositott kiadásában olvasható - mondattal, de a 261. § (1) bekezdés $a$ ) és b) pontja közötti állítólag kötelező kontextusról ott sincsen szó. Két oldallal később, a fejtegetések 7. pontjában a szerző „lehetséges célzatok" bevezetéssel egymástól függetlenként és egyenrangúként sorolja fel az államzsarolási, a megfélemlítési, és a más államokhoz kapcsolódó célzatokat, valamint a követelés kikényszerítését, mint negyediket. ${ }^{32}$ Így az ügyészi álláspont ezzel sem magyarázható.

Azt kell tehát hinnem, hogy e gondolat a vádat képviselő ügyész - jobb esetben a Pest Megyei Föügyészség - elképzelése a terrorista célzatról; a tan-

\footnotetext{
30 Igaz, a jogalkotó nem írt oda „vagy”-ot, mint ahogy más, hasonlóan szerkesztett felsorolásoknál sem, ahol az alternativitás hasonlóképpen magától értődö, például Btk. 211. §; 218. § (1), (2), (3) bekezdés; 221. § (1) bekezdés; 223. § (1) bekezdés; és a felsorolás hosszan folytatható lenne.

31 A Miskolci Egyetem Állam- és Jogtudományi Karán ezt használják: Horváth Tibor - Lévay Miklós (szerk.): Magyar büntetőjog különös rész. Complex Kiadó, Budapest, 2006. A terrorcselekményt a II. kötetben lévő XVI. fejezet (szerzője Lévay Miklós) a 138-141. oldalon tárgyalja. A Szegedi Tudományegyetemen használt tankönyvnek (Kereszty Béla - Maráz Vilmosné - Nagy Ferenc - Vida Mihály: i. m.) a terrorcselekménnyel foglalkozó részét (460-470. o.) Vida Mihály írta. A Pázmány Péter Katolikus Egyetem Jog- és Államtudományi Karán rendszeresített tansegédlet (Belovics Ervin - Molnár Gábor - Sinku Pál: Büntetőjog II. Különös Rész. Hatályosított kiadás. HVG-ORAC, Budapest, 2014) terrorcselekményre vonatkozó fejtegetéseinek (471-474. o.) szerzője Belovics Ervin.

32 Lásd Belovics Ervin - Molnár Gábor - Sinku Pál: i. m. 473. o.
} 
könyvi forrásokra tekintettel azonban nem állítható, hogy egybevágna a Legfőbb Ügyészség véleményével.

A Budapest Környéki Törvényszék is osztotta, sőt sem a Budapesti Fellebbviteli Föügyészség, sem a Budapesti İtélőtábla nem vonta kétségbe ezt a jogértelmezést. E sorok írásakor még nyitott kérdés, hogyan vélekedik a Legföbb Ügyészség és a Kúria. Az eldöntés azonban csak a szakmai igényesség szemszögéből lenne fontos, mert gyakorlati - a büntetés kiszabását érintő jelentősége nincsen.

\section{Néhány zárógondolat}

A szerteágazó és súlyos büncselekmény-sorozat végül lelepleződött, és a bünösöket a bíróság példásan megbüntette - mondhatnánk elégedetten. Ehhez hasonló, békeidőben elkövetett bủncselekmény-sorozatot a magyar kriminalisztika története nem ismer.

Mégsem hiszem, hogy sokan vélnék: ez az ügy a magyar bünüldözés és büntető igazságszolgáltatás történetének fényes lapjaira kerül majd. Nézetem szerint is akkor kerülhetne oda, ha az érintett szervezetek utólag, kíméletlen önkritikával elemeznék a lezajlott eljárást, feltárnák az elkövetett hibákat, és levonnák az adódó tanulságokat, hogy ilyesmi többé ne fordulhasson elö.

Én a nyomozásra vonatkozó, leginkább kiáltó kérdéseknek is csak egy részét hozom szóba. Ezek közé tartozik az, hogy vajon milyen körözési munka kapcsolódott a besenyszögi rabláshoz. Szerepelt-e például a tárgykörözés anyagában az elrabolt hét lőfegyver lehetséges azonosító tárgyaként olyan töltények hüvelye, amelyet kétségtelenül belölük lőttek ki - és ́́gy hordozták a fegyvermüködési nyomokat. Ha igen, hogyan lehetséges, hogy a Bünügyi Szakértői Kutatóintézet ballisztikai szakértői azonosították a Galgagyörkön, Piricsén, Tarnabodon és Nagycsécsen is használt fegyvereket egymás között, de nem azonosították öket a Besenyszögröl elrabolt fegyverekkel? És ami még fontosabb: ha nem volt, miért nem volt ilyen azonosító tárgy? Gazdag Csabáéknál nem maradt kilőtt hüvely sem, vagy ezt nem is tisztázták? Mi az oka annak, hogy - bár 2009. augusztus 21-én megtalálták mind a hét lőfegyvert, amelyek közül többről a vádlottak az egyedi azonosítókat nem is távolították el - 2010 januárjáig nem került szóba az ügyben a besenyszögi fegyverrablás?

Nehezen érthető az is, miként fordulhatott elő a Nemzeti Nyomozó Iroda - azaz az ország legmagasabb szintủ nyomozó hatósága - eljárásában annyi 
és olyan durva kriminalisztikai (vagyis szakmai) hiba és eljárási szabálysértés, mint az elsőfokú ítéletben olvasható. Magyarázat, persze, mindenre van - összességében azonban a dolog mégis aligha menthető, és szerencsére a nyomozási hibák jelentős része orvosolhatónak bizonyult. Ám a kontinentális büntetőeljárási jogi rendszerben a házkutatásról, lefoglalásról stb. éppen azért kell - és szabad - okirati bizonyítási eszközt használni a tárgyaláson, hogy ne tanúvallomások útján kelljen - mint ebben az ügyben történt - tisztázni, hogy mi, hol, és milyen körülmények került a hatóság kezére.

Tanulságok, természetesen, nemcsak a nyomozó hatóságok számára adódnának, hanem a közvádlói hatóság és a bíróságok számára is. Noha a móri ügy nyomán meglehetősen lehangoló kép alakult ki arról, milyen szenvedély füti az igazságszolgáltatás aktorait, hogy a hibákból tanuljanak, gondolom, kialakítható egy olyan módszer, amellyel elejét lehet annak venni, hogy például több hónapi tárgyalást kelljen megismételni azért, mert későn derül ki egy olyan ok, amely miatt ki kell zárni a védőt.

Személyes tapasztalataim szerint az ember a saját, sikeresnek bizonyult ténykedése során elkövetett hibákból tanulhat a legtöbbet. Erősen remélem, hogy az ebben a (végeredményben sikeres) ügyben rejlö töméntelen tanulság sem vész el nyomtalanul. 